\title{
Seed vigor and amount of soybean straw on seedling emergence and productive performance of wheat
}

\section{Vigor de sementes e quantidades de palhada de soja na emergência de plântulas e desempenho produtivo do trigo}

\author{
Julia Abati ${ }^{1 *}$; Cristian Rafael Brzezinski ${ }^{1}$; Claudemir Zucareli²; \\ Flávia Werner'; Fernando Augusto Henning ${ }^{3}$
}

\begin{abstract}
The use of high-quality seeds is essential to minimize the possible suppressive effect of straw on seedling emergence, contributing to stand establishment and high grain yield. The aim of this study was to assess the influence of seed vigor associated with soil cover with different amounts of soybean straw on seedling emergence and productive performance of wheat. The experiment was conducted in a greenhouse using two wheat cultivars (CD 150 and BRS Gralha Azul) under a completely randomized design in a $2 \times 5$ factorial scheme with four replications. Factors consisted of two seed vigor levels (high and low) and five amounts of soybean straw $\left(0,3,6,9\right.$, and $\left.12 \mathrm{tha}^{-1}\right)$. The following assessments were performed: seedling emergence, dry mass of seedling shoot, number of tillers, plant height, yield components (number of spikes per plant, number of grains per spike, and mass of one thousand seeds), grain yield, and harvest index. The use of high vigor seeds favors the emergence and dry mass production of seedling shoot for both cultivars. The increased amount of soybean straw reduces seedling emergence in both cultivars. In the cultivars CD 150 and BRS Gralha Azul, the amounts of soybean straw of 2.45 and $5.40 \mathrm{t} \mathrm{ha}^{-1}$, respectively, result in a higher wheat grain yield.
\end{abstract}

Key words: Seedling establishment. Seed quality. Triticum aestivum L. Vegetation cover.

\section{Resumo}

O uso de sementes de elevada qualidade é fundamental para minimizar o possível efeito supressor da palhada sobre a emergência de plântulas, contribuindo para o estabelecimento do estande e a obtenção de altos rendimentos de grãos. O objetivo foi avaliar a influência do vigor de sementes associado à cobertura do solo com diferentes quantidades de palhada de soja, sobre a emergência de plântulas e o desempenho produtivo da cultura do trigo. O experimento foi conduzido em casa de vegetação, utilizando duas cultivares de trigo (CD 150 e BRS Gralha Azul), sob o delineamento inteiramente casualizado, em esquema fatorial $2 \times 5$, com quatro repetições. Os fatores foram constituídos por dois níveis de vigor de sementes (alto e baixo) e cinco quantidades de palhada de soja $\left(0,3,6,9\right.$ e 12 t ha $\left.^{-1}\right)$. As avaliações efetuadas foram: emergência de plântulas, massa seca da parte aérea de plântulas, número de perfilhos, altura de plantas, componentes do rendimento (número de espigas por planta, número de grãos por espiga e massa de mil sementes), produtividade de grãos e índice de colheita. A utilização de sementes de alto vigor favorece a emergência e a produção de massa seca da parte aérea das plântulas,

\footnotetext{
${ }^{1}$ Discentes, Curso de Doutorado, Programa de Pós-Graduação em Agronomia, Universidade Estadual de Londrina, UEL, Centro de Ciências Agrárias, CCA, Londrina, PR, Brasil. E-mail: juliaabati@yahoo.com.br; cristian_brzezinski@yahoo.com.br; flawerner6@gmail.com

2 Prof. Dr., Departamento de Agronomia, CCA/UEL, Londrina, PR, Brasil. E-mail: claudemircca@uel.br

3 Pesquisador Dr., Empresa Brasileira de Pesquisa Agropecuária, Centro Nacional de Pesquisa de Soja, EMBRAPA Soja, Londrina, PR, Brasil. E-mail: fernando.henning@embrapa.br

* Author for correspondence
} 
para ambas cultivares. $\mathrm{O}$ aumento da quantidade de palhada de soja reduz a emergência de plântulas, nas duas cultivares. Nas cultivares CD 150 e BRS Gralha Azul, as quantidades de palhada de soja de 2,45 e 5,40 tha ${ }^{-1}$, respectivamente, resultam em maior produtividade de grãos de trigo.

Palavras-chave: Cobertura vegetal. Estabelecimento de plântulas. Qualidade de sementes. Triticum aestivum $\mathrm{L}$.

Wheat crop (Triticum aestivum L.) stands out in the Brazilian and international agricultural scene due to its importance for human and animal feed, production of non-food products, and the benefits generated by the agricultural production system. In Brazil, wheat is one of the main winter crops, mainly in the southern region, being integrated into the no-tillage system, in rotation/succession mainly with soybean and corn crops.

In the crop rotation/succession system, the maintenance of crop residues (straw) on the soil surface provides several benefits such as the energy dissipation of raindrop impact, increase in water infiltration, moisture preservation, improvement of macro and micro fauna activity present in the soil and nutrient cycling efficiency, and reduction of thermal amplitude, erosion losses, and weed incidence (ANDRIOLI et al., 2008; CHIODEROLI et al., 2012).

Quantity and quality of straw on the soil surface are conditioned to the decomposition rate of plant material and depend to a great extent on plant type, management, and edaphoclimatic conditions. The influence of straw from different crops on the percentage of soil cover was reported by Silva et al. (2006), who observed that with $3.5 \mathrm{tha}^{-1}$ of residues of soybean, millet, and corn, about 35,25 , and $20 \%$ of soil surface were unprotected, respectively.

Soil biomass left on the soil surface is approximately $2.5 \mathrm{t} \mathrm{ha}^{-1}$ (RUEDELL, 1998). However, a lack of uniformity in straw distribution has been observed as a function of mechanized harvest (KUNZ et al., 2008), resulting in sites with a greater straw accumulation.

Depending on the amount of straw present on the soil due to the high crop biomass production or the occurrence of sites with accumulation, a physical barrier is formed, which may delay and/or prevent seedling emergence, possibly compromising the required plant stand, growth, development, and yield of the wheat crop. Thus, technologies that aim to minimize the possible suppressive effect of straw on seedling emergence are necessary and, among them, the use of high-quality seeds stands out.

Seeds of quality are characterized by a high physiological performance such as high germination and vigor rates, associated with genetic, physical, and sanitary characteristics. Among quality attributes, seed vigor plays a relevant role in agricultural production since more vigorous seeds provide a rapid and uniform germination, favoring shoot and root system growth, giving the plant better development conditions, as well as a greater ability to withstand adverse environmental conditions during germination process (CARVALHO; NAKAGAWA, 2012).

When assessing the effect of seed vigor on black oat, Schuch et al. (2000) observed that the use of high vigor seeds resulted in a greater seedling emergence under field conditions. Furthermore, Melo et al. (2006) observed that rice plants originated from high vigor seeds showed better performance in terms of leaf area, tillering, number of panicles per plant, and grain yield when compared to low vigor seeds.

Given the above and considering that wheat sowing is usually carried out after soybean cultivation, the aim of this study was to assess the influence of seed vigor associated with soil cover with different amounts of soybean straw on seedling emergence and the productive performance of the wheat crop. 
The experiment was carried out in a greenhouse model Van der Hoeven ${ }^{\circledR}$ at the State University of Londrina (UEL), Londrina, Paraná, Brazil. The assessed wheat cultivars were CD 150 and BRS Gralha Azul, which present an early and medium cycle, with an average ripening of 114 and 124 days, respectively. The experimental design was completely randomized design in a $2 \times 5$ factorial scheme with four replications for both cultivars. Factors consisted of two seed vigor levels (high and low) and five amounts of soybean straw $(0,3,6,9$, and $12 \mathrm{tha}^{-1}$ ).

Low vigor seeds were obtained from seed lots with high vigor by means of the accelerated aging technique application. To conduct the aging, seeds were placed into crystal polystyrene boxes (Gerbox ${ }^{\circledR}$ type) with screened supports and containing $40 \mathrm{~mL}$ distilled water. Subsequently, these boxes were conditioned in a water-jacketed incubation chamber under a temperature of $42{ }^{\circ} \mathrm{C}$ for a period of 60 hours, leading to a reduction in seed vigor. Seeds not submitted to the accelerated aging were considered as having high vigor.

To characterize both low and high seed vigor lots to be used, seed physiological quality was determined by the following tests: germination and first germination count, which were performed according to the Rules for Testing Seeds (BRASIL, 2009); length of seedling, shoot, and root were carried out according to the methodology proposed by Nakagawa (1999); dry mass of shoot and root were performed according to Nakagawa (1999); emergence speed index was conducted under greenhouse conditions using the equation suggested by Popinigis (1977); and seedling emergence in sand by counting the total emerged seedlings at 12 days after sowing.

The results to characterize seed physiological quality with high (HV) and low vigor (LV) were: germination $(\%)-\mathrm{CD} 150=\mathrm{HV}: 90 / \mathrm{LV}: 80$ and BRS Gralha Azul = HV: 98 / LV: 94; first germination count $(\%)-\mathrm{CD} 150=\mathrm{HV}$ : 85 / LV:
74 and BRS Gralha Azul = HV: 96 / LV: 89; total length of seedling, shoot, and root $(\mathrm{cm})-\mathrm{CD} 150$ $=\mathrm{HV}: 20.76,8.60,12.16 / \mathrm{LV}: 15.99,7.09,8.90$ and BRS Gralha Azul = HV: 21.23, 7.88, $13.34 /$ LV: 20.13, 7.24, 12.89; dry mass of shoot and root $(\mathrm{mg}$ per seedling $)-\mathrm{CD} 150=\mathrm{HV}: 5.63,6.18 / \mathrm{LV}$ : 5.27, 4.31 and BRS Gralha Azul = HV: 7.84, 8.70 / LV: 7.29, 8.17; emergence speed index - CD 150 = HV: $19.13 / \mathrm{LV}: 16.10$ and BRS Gralha Azul = HV: 20.58 / LV: 18.70; seedling emergence in sand $(\%)-\mathrm{CD} 150=\mathrm{HV}: 87$ / LV: 80 and Gralha Azul $=$ HV: 96 / LV: 94.

Prior to the experiment installation, soil samples were collected to analyze chemical characteristics. The results were: $\mathrm{pH}\left(\mathrm{CaCl}_{2}\right): 5.2 ; \mathrm{C}: 1.71 \mathrm{~g} \mathrm{~kg}^{-1} ; \mathrm{P}$ : $6.87 \mathrm{mg} \mathrm{dm}^{-3} ; \mathrm{H}^{+}+\mathrm{Al}^{+3}: 4.61 \mathrm{cmol}_{\mathrm{c}} \mathrm{dm}^{-3} ; \mathrm{Al}^{+3}: 0.03$ $\mathrm{cmol}_{\mathrm{c}} \mathrm{dm}^{-3} ; \mathrm{K}^{+}: 0.54 \mathrm{cmol}_{\mathrm{c}} \mathrm{dm}^{-3} ; \mathrm{Ca}^{+2}: 9.02 \mathrm{cmol}_{\mathrm{c}}$ $\mathrm{dm}^{-3} ; \mathrm{Mg}^{+2}: 0.43 \mathrm{cmol}_{\mathrm{c}} \mathrm{dm}^{-3}$; OM: $2.95 \mathrm{~g} \mathrm{~kg}^{-1}, \mathrm{CEC}$ : $14.6 \mathrm{cmol}_{\mathrm{c}} \mathrm{dm}^{-3}$, and BS: $68.42 \%$. Soil fertilization was performed with $270 \mathrm{~kg} \mathrm{ha}^{-1}$ of the formulated fertilizer 15-15-15 (N-P-K). At the beginning of tillering phase, a topdressing nitrogen fertilization was performed using as fertilizer the urea, which corresponded to $40 \mathrm{~kg} \mathrm{~N} \mathrm{ha}^{-1}$.

Seeds were treated with the insecticide Gaucho ${ }^{\circledR}$ (imidacloprid) at a dose of $100 \mathrm{~mL} 100 \mathrm{~kg}^{-1}$ of seeds and fungicide Vitavax-Thiram ${ }^{\circledR}$ (carboxin + thiram) at a dose of $250 \mathrm{~mL} 100 \mathrm{~kg}^{-1}$ of seeds. Sowing was carried out in pots with a volume of nine liters of soil. Twenty seeds were sown in each pot at a depth of $4 \mathrm{~cm}$. Subsequently, the five amounts of soybean straw were added to the soil simulating 0 (control without soil cover), 3, 6, 9, and $12 \mathrm{t} \mathrm{ha}^{-1}$. The following assessments were carried out:

Seedling emergence: at 15 days after sowing, the total number of seedlings emerged in each pot was counted. The results were expressed in percentage.

Dry mass of seedling shoot: after the assessment of seedling emergence, thinning was performed, leaving only three seedlings per pot. The shoots of the plucked seedlings were placed in paper bags and taken to a forced air circulation oven at a 
temperature of $80^{\circ} \mathrm{C}$ for 24 hours (NAKAGAWA, 1999). Subsequently, the dry mass of shoot was assessed on a precision balance with an accuracy of $0.001 \mathrm{~g}$. The results were expressed in $\mathrm{mg}$ per seedling.

Number of tillers per plant: at the crop booting stage, the total number of tillers per plant was counted.

Plant height: at the ripening stage of harvest, the height of the three plants in the pot was measured from the soil surface to the spike apex of the main stem without counting the awns. The results were expressed in $\mathrm{cm}$.

Yield components: the following components were assessed at the ripening stage: number of spikes per plant, counted from the total number of spikes per plant; number of grains per spike, determined by the ratio of total number of grains to total number of spikes; mass of one thousand seeds (MTS), obtained with the use of two subsamples of 100 seeds per replication, with results expressed in grams (BRASIL, 2009).

Grain yield: this variable was obtained by weighing the grains harvested in each experimental plot, with moisture corrected to $13 \%$. The results were expressed in grams per plant.

Harvest index: this index was determined by the ratio between the mass of grains and the total mass of shoot of the three harvested plants. The obtained indices were multiplied by 100 in order to express the results in percentage.

The data obtained were analyzed for normality and homoscedasticity by using the Shapiro-Wilk and Hartley tests, respectively. Subsequently, results were submitted to analysis of variance and means compared by the Tukey's test at 5\% probability separately for each cultivar. For the straw factor, the data were submitted to regression analysis.

No interaction was observed between the studied factors for all the assessed characteristics. Thus, only the significant effects isolated from the seed vigor and soybean straw were presented.

In both cultivars, the use of high vigor seeds provided a higher number of emerged seedlings when compared to low vigor seeds (Table 1). These results show the importance of seed vigor in crop implantation since the use of high vigor seeds resulted in a greater seedling emergence regardless of the conditions of soil cover with soybean straw.

Table 1. Seedling emergence (\%) and dry mass of shoot (mg per seedling) considering the average of five amounts of soybean straw for vigor effect of wheat seeds on the cultivars CD 150 and BRS Gralha Azul.

\begin{tabular}{ccc}
\hline \multirow{2}{*}{ Vigor } & \multicolumn{2}{c}{ CD 150 } \\
\cline { 2 - 3 } & Seedling emergence & Dry mass of shoot \\
\hline High & $65 \mathrm{~A}$ & $23.80 \mathrm{~A}$ \\
Low & $54 \mathrm{~B}$ & $20.97 \mathrm{~B}$ \\
CV $(\%)$ & 12.71 & 17.91 \\
\hline & \multicolumn{3}{|c}{ BRS Gralha Azul } \\
\hline High & $79 \mathrm{~A}$ & $31.90 \mathrm{~A}$ \\
Low & $68 \mathrm{~B}$ & $28.51 \mathrm{~B}$ \\
\hline CV $(\%)$ & 7.53 & 10.38 \\
\hline
\end{tabular}

Means followed by the same letter in each column do not differ from each other by the Tukey's test at 5\% probability.

During seed germination process a sequence of biochemical reactions occurs and reserve substances are unfolded, transported, and resynthesized in the embryonic axis, culminating in seedling formation.
However, in lower vigor seeds, these events are impaired, especially under adverse environmental conditions (BEWLEY et al., 2013), justifying the results obtained for seedling emergence. 
In addition, a decreasing linear behavior was observed for seedling emergence as the amount of soybean straw increased in both cultivars (Figure 1A). This result is possibly related to the greater amount of biomass on the soil to act as a physical barrier, preventing seedling emergence.
Furthermore, according to Lamego et al. (2015), this barrier can damage seedlings, causing them to be etiolated by means of a quantity and quality luminous radiation search mechanism, making them more susceptible to mechanical damage during crop cycle and consuming reserves that could be used in plant development.

Figure 1. Seedling emergence (A), number of tillers per plant (B), number of spikes per plant (C), grain yield (D), and harvest index (E) in the cultivars CD 150 and BRS Gralha Azul, average of two seed vigor levels, as a function of the amount of soybean straw on the soil surface.
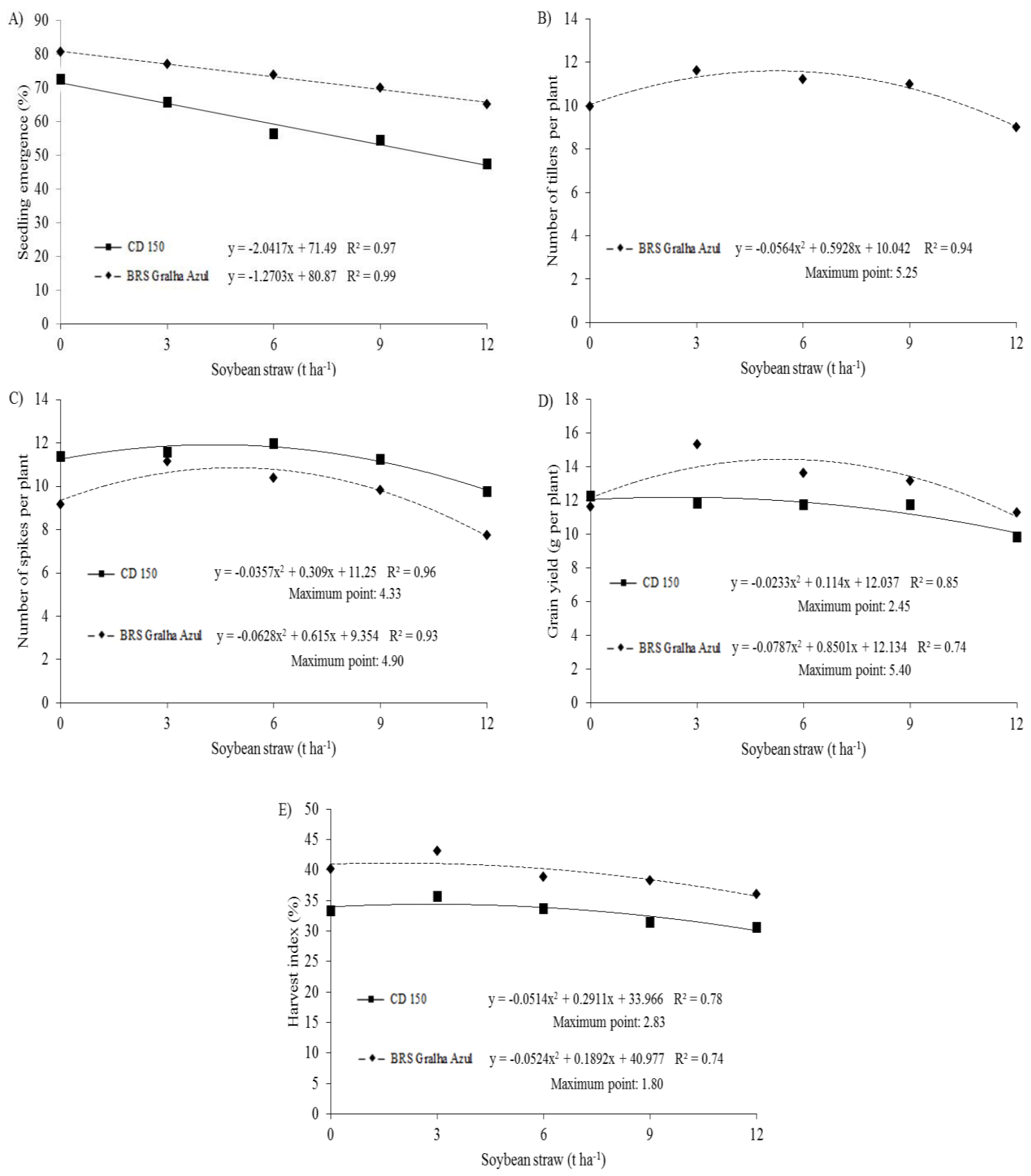
High vigor seeds resulted in seedlings with a higher dry mass of shoot when compared to those from low vigor seeds, in both cultivars (Table 1). Similar effects were also observed in oat (SCHUCH et al., 2000), soybean (KOLCHINSKI et al., 2006), rice (MELO et al., 2006), and corn crops (MONDO et al., 2013).

These results are in accordance with those described by Carvalho and Nakagawa (2012), in which seedlings originated from high vigor seeds emerged and started the photosynthetic process faster, favoring shoot growth. More vigorous seeds present a greater capacity of transforming the reserve supply in the storage tissues and incorporating it into the embryonic axis (BEWLEY et al., 2013).

For the number of tillers per plant, a significant effect of straw was observed only on the cultivar BRS Gralha Azul, which presented a quadratic behavior with a lower number of tillers in the amount of $12 \mathrm{tha}^{-1}$ and a maximum production of tillers with $5.25 \mathrm{t} \mathrm{ha}^{-1}$ of soybean straw on the soil surface (Figure 1B).

Straw on the soil modifies the microclimate, favoring, to a certain extent, tiller production by plants. However, a reduction in light incidence is observed as vegetal cover increases, negatively affecting tillering. Tillering capacity of plants depends directly on environmental conditions, as well as genetic, hormonal, and nutritional factors (VALÉRIO et al., 2009).

The number of spikes per plant in the cultivar CD 150 was adjusted to a quadratic equation in response to the amount of soybean straw, with a point of maximum spike production per plant with $4.33 \mathrm{t} \mathrm{ha}^{-1}$ (Figure 1C). Similar behavior was observed in the cultivar BRS Gralha Azul, but the maximum response point was $4.90 \mathrm{t} \mathrm{ha}^{-1}$ (Figure 1C). These results corroborate those found by Noce et al. (2008), who reported that several factors are related to the straw effects on plant growth and development such as the amount of straw produced.

Regarding grain yield per plant, the maximum yield was obtained with 2.45 and $5.40 \mathrm{t} \mathrm{ha}^{-1}$ of soybean straw on the soil surface for the cultivars CD 150 and BRS Gralha Azul, respectively (Figure 1D). In addition, the cultivar BRS Gralha Azul presented the closest maximum response points among the variables number of tillers per plant, number of spikes per plant, and grain yield. However, the point of maximum response for grain yield in the cultivar CD 150 was lower in relation to that observed for the number of spikes per plant (4.33 $\mathrm{t} \mathrm{ha}^{-1}$ ), thus demonstrating that yield depends on a set of yield components and not only of an isolated component, in addition to being dependent on the genetic effect.

Studying the response of corn genotypes cultivated under different amounts of black oat straw, Sá et al. (2011) also observed that the genotypes have different behavior in relation to the amount of straw on the soil surface produced by the predecessor crop, similar to that observed for the wheat crop in this study.

For the harvest index, an isolated effect of straw was observed for both cultivars. As in the other assessed variables, the higher amount of soybean straw on the soil $\left(12 \mathrm{t} \mathrm{ha}^{-1}\right)$ resulted in a lower harvest index (Figure 1E).

From the results obtained and considering the expression and relevance of using agricultural systems that maintain the vegetal cover (straw) on the soil surface, it is worth noting that, regardless of the amount of soybean straw, the use of vigorous seeds is required.

The use of high vigor seeds favors the emergence and establishment of the seedling stand, as well as the dry mass production of seedling shoot for both cultivars.

The increased amount of soybean straw on the soil surface reduces seedling emergence in both wheat cultivars.

In the cultivars CD 150 and BRS Gralha Azul, straw amounts of 2.45 and $5.40 \mathrm{tha}^{-1}$, respectively, result in a higher grain yield per plant. 


\section{References}

ANDRIOLI, I.; BEUTLER, A. N.; CENTURION, J. F.; ANDRIOLI, F. F.; COUTINHO, E. L. M. Produção de milho em plantio direto com adubação nitrogenada e cobertura do solo na pré-safra. Revista Brasileira de Ciência do Solo, Viçosa, MG, v. 32, n. 4, p. 1691-1698, 2008.

BEWLEY, J. D.; BRADFORD, K. J.; HILHORST, H. W. M.; NONOGAKI, H. Seeds: physiology of development, germination and dormancy. $3^{\text {th }}$ ed. [S.1.]: Springer, 2013. $407 \mathrm{p}$.

BRASIL. Ministério da Agricultura, Pecuária e Abastecimento. Regras para análise de sementes. Ministério da Agricultura, Pecuária e Abastecimento. Secretaria de Defesa Agropecuária. Brasília: MAPA/ ACS, 2009. 395 p.

CARVALHO, N. M.; NAKAGAWA, J. Sementes: ciência, tecnologia e produção. Jaboticabal: FUNEP, 2012. $590 \mathrm{p}$.

CHIODEROLI, C. A.; MELLO, L. M. M.; GRIGOLLI, P. J.; FURLANI, C. E. A.; SILVA, J. O. R.; CESARIN, A. L. Atributos físicos do solo e produtividade de soja em sistema de consórcio milho e braquiária. Revista Brasileira de Engenharia Agrícola e Ambiental, Campina Grande, v. 16, n. 1, p. 37-43, 2012.

KOLCHINSKI, E. M.; SCHUCH, L. O. B.; PESKE, S. T. Crescimento inicial de soja em função do vigor de sementes. Revista Brasileira de Agrociência, Pelotas, v. 12, n. 2, p. 163-166, 2006.

KUNZ, V. L.; GABRIEL FILHO, A.; PRIMO, M. A.; GURGACZ, E. F. Distribuição de palha por colhedoras autopropelidas na colheita da soja. Engenharia Agrícola, Jaboticabal, v. 28, n. 1, p. 125-135, 2008.

LAMEGO, F. P.; REINEHR, M.; CUTTI, L.; AGUIAR, A. C. M.; RIGON, C. A. G.; PAGLIARINI, I. B. Alterações morfológicas de plântulas de trigo, azevém e nabo quando em competição nos estádios iniciais de crescimento. Planta Daninha, Viçosa, MG, v. 33, n. 1, p. 13-22, 2015.

MELO, P. T. B. S.; SHUCH, L. O. B.; ASSIS, F. N.; CONCENÇO, G. Comportamento individual de plantas originadas de sementes com diferentes níveis de qualidade fisiológica em populações de arroz irrigado. Revista Brasileira de Sementes, Londrina, v. 28, n. 2, p. 84-94, 2006.
MONDO, V. H. V.; CICERO, S. M.; DOURADO NETO, D.; PUPIM, T. L.; DIAS, M. A. N. Seed vigor and initial growth of corn crop. Journal of Seed Science, Londrina, v. 35, n. 1, p. 64-69, 2013.

NAKAGAWA, J. Teste de vigor baseados no desempenho das plântulas. In: KRZYZANOWSKI, F. C.; VIEIRA, R. D.; FRANÇA NETO, J. B. Vigor de sementes: conceitos e testes. Londrina: ABRATES, 1999. p. 2.1-2.24.

NOCE, M. A.; SOUZA, I. F.; KARAM, D.; FRANÇA, A. C.; MACIEL, G. M. Influência da palhada de gramíneas forrageiras sobre o desenvolvimento da planta de milho e das plantas daninhas. Revista Brasileira de Milho e Sorgo, Sete Lagoas, v. 7, n. 3, p. 265-278, 2008.

POPINIGIS, F. Fisiologia da semente. Brasília: AGIPLAN, 1977. 289 p.

RUEDELL, J. A soja numa agricultura sustentável. In: SILVA, M. T. B. da. (Ed.). A soja em rotação de culturas no plantio direto. Cruz Alta: Fundacep: Fecotrigo, 1998. p. 1-34.

SÁ, J. C. M.; FERREIRA, A. O.; BRIEDIS, C.; VIEIRA, A. M.; FIGUEIREDO, A. G. Extração de nutrientes e produtividade de genótipos de milho afetados por níveis de palha. Acta Scientiarum. Agronomy, Maringá, v. 33, n. 4, p. 715-722, 2011.

SCHUCH, L. O. B.; NEDEL, J. L.; ASSIS, F. N.; MAIA, M. S.; ROSENTHAL, M. D. Emergência no campo e crescimento inicial de aveia preta em resposta ao vigor das sementes. Revista Brasileira de Agrociência, Pelotas, v. 6, n. 2, p. 97-101, 2000.

SILVA, F. A. M.; PINTO, H. S.; SCOPEL, E.; CORBEELS, M.; AFFHOLDER, F. Dinâmica da água nas palhadas de milho, milheto e soja utilizadas em plantio direto. Pesquisa Agropecuária Brasileira, Brasília, v. 41, n. 5, p. 717-724, 2006.

VALÉRIO, I. P.; CARVALHO, F. I. F.; OLIVEIRA, A. C.; BENIN, G.; MAIA, L. C.; SILVA, J. A. G.; SCHMIDT, D. M.; SILVEIRA, G. Fatores relacionados a produção e desenvolvimento de afilhos em trigo. Semina: Ciências Agrárias, Londrina, v. 30, p. 1207-1218, 2009. Suplemento 1. 
